\title{
Physiological Characteristics and Growth Performances of Container-grown Seedlings of Broad-leaved Evergreen Cinnamomum yabunikkei and Neolitsea sericea with Different Fertilization Levels
}

\author{
Eon-Ju Jin ${ }^{1}$, Min-Gi Cho' ${ }^{1}$, Hak-Gon Kim² , Kwang-Soo Lee ${ }^{1}$, and Eun-Ji Bae ${ }^{1}$ * \\ ${ }^{1}$ Southern Forest Resources Research Center, National Institute of Forest Science, Seoul 02455, South Korea \\ ${ }^{2}$ Gyeongsangnam-do Forest Environment Research Institute, Jinju 51615, South Korea
}

\begin{abstract}
The purpose of this study was to identify optimum fertilization technology for Neolitsea sericea and Cinnamomum yabunikkei, which are major species of broad-leaved afforestation trees. Depending on the treatment of water soluble fertilizers ( $N: P: K=19: 19: 19, \mathrm{v} / \mathrm{V} / \mathrm{V}$ ), changes in root collar diameter, plant height, dry weight, and seedling quality index were measured as growth characteristics and changes in photochemical efficienty and chlorophyll content as physiological characteristics. After analyzing growth characteristics the highest root diameter and plant height growth were observed in $1.5 \mathrm{gL}$ concentration in the case of $N$. sericea, and $1.0 \mathrm{~g} \cdot \mathrm{L}^{-1}$ in the case of $C$. yabunikkei. The H/D ratios in these fertilizer concentrations showed $7.0 \mathrm{~cm} \cdot \mathrm{mm}^{-1}$ for $N$. sericea and $9.3 \mathrm{~cm} \cdot \mathrm{mm}^{-1}$ for $C$. yabunikkei, which were significantly higher than any other concentrations. N. sericea and C. yabunikkei had high total dry weight, $5.92 \mathrm{~g}$ in the $1.5 \mathrm{~g} \cdot \mathrm{L}^{-1}$ treated area, and $6.01 \mathrm{~g}$ in the $1.0 \mathrm{~g} \cdot \mathrm{L}^{-1}$ treated area, respectively. The $\mathrm{T} / \mathrm{R}$ ratio and seedling quality index were also significantly higher in the fertilization treatment area of high dry weight. As a result of analysis of physiological characteristics the photochemical efficiency and chlorophyll content were lower than those of healthy leaves in both species, with high values of $1.5 \mathrm{~g} \cdot \mathrm{L}^{-1}$ in the case of $N$. sericea, and $1.0 \mathrm{~g} \cdot \mathrm{L}^{-1}$ in the case of $C$. yabunikkei. According to the overall results of this study, the optimum fertilization level varies depending on the nutritional needs of respective species, and the fertilizer application rates of water soluble fertilizer suitable for the production of 2-year-old containerized seedling of $N$. sericea and $C$. yabunikkei were 1.5 $\mathrm{g} \cdot \mathrm{L}^{-1}$ and $1.0 \mathrm{~g} \cdot \mathrm{L}^{-1}$, respectively. However, it is difficult to predict the adaptation characteristics of the trees to long-term changes when using fertilizers, because this study is the analysis of the short term responses from 2 year old young seedlings. In addition, they are cultivated in greenhouses or nursery field; in this case, it is believed to be necessary to study the response of trees to rapid changes of future climate. Additionally, since the response to fertilizer concentration varies greatly depending on the tree species, it is necessary to continuously study major tree species in Korea and other species that are sensitive to climate changes.
\end{abstract}

Keywords: chlorophyll contents, H/D ratio, photochemical efficiency, SQI

\section{Introduction}

Cinnamomum yabunikkei and Neolitsea sericea are broad-leaved evergreen camphor trees observed in the warm 
temperature zone in Korea, and they were selected among the 300 plant species for climate change adaptation on the Korean Peninsula (KFS, 2013). According to a report published by the Korea Forest Service (2013), an area of approximately 20,000 ha is forested annually in Korea, and broad-leaved trees account for $55 \%$ of the total forested area. In addition, broad-leaved evergreens in the warm temperate zone have been revalued recently as biological and genetic resources and ecological tourism resources. Studies have been conducted on the distribution and ecological characteristics of these species and interest in the restoration of damaged forests in warm temperate zones has grown (Park et al., 2010).

As the demand for domestic broad-leaved trees has grown recently, it is necessary to research and develop technologies to cultivate and plant broad-leaved seedlings. However, there are only a few fundamental studies on the production and growth of broad-leaved evergreens, and the structure of production. In addition, due to abnormal weather events that frequently occur, seedlings in open fields are often flooded during localized torrential downpours in summer and are damaged by frost in winter (Kim et al., 2010). Therefore, it is time to develop technologies to mass-produce high-quality seedlings in greenhouses and to respond to rising labor costs. In Korea, since seedlings of only few broad-leaved trees such as Quercus myrsinaefolia, and Quercus acutissima Carruth are grown in containers, the demand for producing a wider range of container-grown broad-leaved trees is on the rise in the forestry industry (Kwon et al., 2009).

In general, various factors are involved in the process of greenhouse cultivation such as light, temperature, humidity, container type, bed soil, and fertilization techniques (Grossnickle, 2005; Aghai et al., 2014). Among them, fertilizers must be applied to plants grown in containers filled with bed soil (Broschat, 1995). In particular, the quality of container-grown seedlings changes depending on fertilization techniques and the subsequent physiological and growth characteristics and nutrient loading of seedlings (Landis et al., 1989). Since improvement in the drought and cold resistance, survival and growth of container-grown seedlings and their competitiveness with low vegetation, and reduction in stress from transplanting are observed only after transplanting seedlings into a forested land, suitable fertilization techniques need to be used to meet the different nutrient uptake of various species and thus to produce high-quality container-grown seedlings, and to improve the performances of afforestation (Cho et al., 2012; Dumroese et al., 2013).

However, repetitive fertilization causes environmental issues in soil and stream water near greenhouses (Juntunen et al., 2003), and excess or deficiency in nutrients can affect the physiological characteristics of species, resulting in low-quality seedlings (Lee et al., 2006). Therefore, to ensure seedlings grow and take root well after transplanting, different fertilization techniques should be applied to different species, and many studies have been conducted on its effects both in Korea and overseas (Ingestad, 1979; Phillion and Libby, 1984; Shin et al., 1999; Byun et al., 2007; Kwon et al., 2009; Sung et al., 2011).

Meanwhile, no matter in which system seedlings are cultivated, their morphological and physiological characteristics are closely related to their high survival rate, plant length and root collar diameter after transplanting. These are key factors to the success of afforestation. The morphological characteristics of seedlings include the size of seedlings (plant length, root collar diameter, etc.), the dry weight of each part and the $\mathrm{T} / \mathrm{R}$ ratio (top/root dry weight ratio) and other quality evaluation indicators. The H/D ratio [plant height $(\mathrm{cm}) /$ root collar diameter $(\mathrm{mm})$ ], an indicator used to evaluate the healthiness of seedlings, is determined as a ratio of the height of a plant to its root collar diameter (Thompson, 1985; Haase, 2007). The lower the dry weight, H/D ratio and T/R ratio (leaf+shoot dry weight/root dry weight) of seedlings, the higher the seedling quality index [SQI = seedling dry weight $(\mathrm{g}) /(\mathrm{H} / \mathrm{D}$ ratio $+\mathrm{T} / \mathrm{R}$ ratio)], which is recognized as a relatively healthy seedling (Bayala et al., 2009).

Likewise, key morphological characteristics can be used to evaluate the quality of seedlings (Landis et al., 1989; Haase, 2007), and the quality of produced seedlings is evaluated later based on the survival and growth rates of seedlings after transplanting (Landis et al., 1995). Against this background, this study aimed to identify the growth and physiological 
changes in seedlings of Cinnamomum yabunikkei and Neolitsea sericea, selected as species for climate change adaptation, depending on the concentration of fertilizers. In particular, the low survival rate of the seedlings of camphor trees after planting is attributable to the characteristics of deep-rooted tree species, such as the low growth of rootlets of seedlings. This study focused on the effects of the different concentrations of a fertilizer on the growth and physiological characteristics of camphor tree species. Data on the proper concentrations of the fertilizer for each species obtained in this study can be utilized to establish a system for producing container-grown seedlings of evergreen broad-leaved camphor trees.

\section{Methods}

\section{Test site and species}

This study was conducted in a glass greenhouse located in the Southern Forest Resources Center of the National Institute of Forest Science in Jinju, South Gyeongsang Province. Cinnamomum yabunikkei and Neolitsea sericea used in this study were 2-year old seedlings bought from the Wando Forestry Cooperative. The two species were grown from February, 23, 2015 for 2 months in a glass greenhouse in the Southern Forest Resources Center, and a total of 75 seedlings (15 seedlings $\mathrm{x}$ repeating 5 times) of a similar size for each species were selected and transplanted into containers (diameter $16 \mathrm{~cm} \times$ height $20 \mathrm{~cm}$ ). Nursery bed soil used in this study was composed of peat moss, perlite and vermiculite $(1: 1: 1, \mathrm{v} / \mathrm{v} / \mathrm{v})$ (Tobi Tech, Korea), and underground water was watered for each container everyday (20 L/day) before treating them with the fertilizer. Seedlings transplanted into containers were grown in a greenhouse for one month to ensure they take root. After one month, the average length of Cinnamomum yabunikkei was $10.3 \pm 0.5 \mathrm{~cm}$, and that of Neolitsea sericea, $8.2 \pm 1.9 \mathrm{~cm}$.

\section{Treatment with a fertilizer}

A water soluble fertilizer, MultiFeed 19 (N:P:K=19:19:19, Haifa Chemicals, Israel), was applied once a week from June 3 to September 24, 2015, a total of 16 times. The concentrations of the fertilizer were $0.0,0.5,1.0,1.5$ and $2.0 \mathrm{~g} \cdot \mathrm{L}^{-1}$, and it was applied once a week along with watering. For each species, 15 trees were planted in one container (a total of 17 trees in 5 containers). They were not watered on the same day when they were treated with the fertilizer, and $5 \mathrm{~L}$ of a diluted solution mixed with each concentration of the fertilizer (including the control group) was poured in a watering pot and sprayed over the seedlings.

\section{Growth and physiological characteristics}

\section{Growth characteristics}

For each species, 5 trees from June 3, 2015 before treating with the fertilizer, and 5 trees after treating with the fertilizer to September 24, 2015 were selected to identify the growth characteristics of each species depending on the concentration of the fertilizer (a total of 20 trees). Their root collar diameter and plant length were measured every 20 days repeatedly and their growth and relative growth rate (RGR) were analyzed based on the results. The relative growth rate was calculated as a ratio of the root collar diameter and plant length before treatment for each unit period (day $\left.{ }^{-1}\right)$ to the total cultivation period (Hughes and Freeman, 1967), and the H/D ratio [SQ; sturdiness quotient $=$ height $(\mathrm{cm}) /$ root collar diameter (mm)] was also calculated to evaluate the healthiness of seedlings (Bayala et al., 2009). Electric calipers and steel tapes were used to measure the root collar diameter and length of seedlings. After completing all the test in the 
middle of September, 10 trees of each treatment group (a total of 50 trees) were sampled and their roots, stems and leaves were collected separately. After drying them at $65^{\circ} \mathrm{C}$ for 48 hours in a drier, their dry weight was measured. Based on the results, the dry weight and T/R ratio of each tree were calculated (Šestak et al., 1971; Dominguez-Lerena et al., 2006). In addition, the seedling quality index [SQI $=$ seedling dry weight $(\mathrm{g}) /(\mathrm{H} / \mathrm{D}$ ratio $+\mathrm{T} / \mathrm{R}$ ratio $)]$ was calculated to comprehensively evaluate the quality of container-grown seedlings (Deans et al., 1989).

\section{Physiological characteristics}

\section{Chlorophyll fluorescence reaction}

Photochemical efficiency is an important indicator of stress on growth environments, and was analyzed by measuring the maximum net apparent quantum yield $\left(\mathrm{F}_{\mathrm{v}} / \mathrm{F}_{\mathrm{m}}\right)$ of the optical reaction of each group treated with the different concentration of the fertilizer. To do so, a clip was put into the center of the $2^{\text {nd }}$ or $3^{\text {rd }}$ leaf from the top to darken the leaf for 20 minutes, and their chlorophyll fluorescence reaction was measured using a kinetic imaging fluorometer (FluorCam, Photon System Instruments, Czech) once a week, and the process was repeated 3 times by species and group. Their fluorescence reaction was measured after placing a target container in a light-tight darkroom for 15 minutes to ensure the seedling adapt to darkness. A ray of $2000 \mu \mathrm{mol} \cdot \mathrm{m}^{-2} \cdot \mathrm{m}^{-1}$ was applied (Choi and Kim, 1995; Demmig and Bjorkman, 1987), and the initial fluorescence reaction $\left(F_{0}\right)$, maximum fluorescence reaction $\left(F_{m}\right)$, maximum change $\left(F_{v}=F_{m}-F_{0}\right)$ and optical reaction efficiency $\left(\mathrm{F}_{\mathrm{v}} / \mathrm{F}_{\mathrm{m}}\right)$ of seedlings were measured and compared.

\section{Chlorophyll content analysis}

The photopigment content in leaves tends to decrease under stress, and thus it has been widely used as an indicator of stress, which shows a big difference between species (Han et al., 2009; Kim et al., 2001). To examine changes in the chlorophyll content depending on the concentration of the fertilizer for each species, the method of Hiscox and Israelstam (1979) that uses DMSO (dimethylsulfoxide) as a solvent was used to extract chlorophyll from seedlings. The absorbance of the extracted liquid was measured at $663 \mathrm{~nm}$ (A663) and $645 \mathrm{~nm}$ (A645) using an UV-visible spectrophotometer (Nicolet Evolution 100, Thermo Electron Co., USA), and calculated using the following equations.

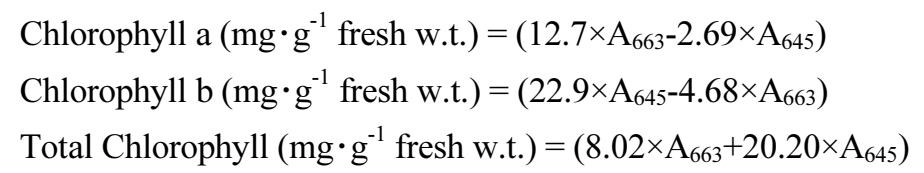

\section{Statistical analysis}

The data measured depending on the concentration of the fertilizer were compared and analyzed based on the significance of each treatment section analyzed using Duncan's multiple range test, and all the statistics were analyzed using SPSS version 18 (SPSS Inc., Chicago, Illinois, USA, 2003).

\section{Results and Discussion}

\section{Growth characteristics}

\section{Growth of root collar diameter and plant length}

The size of seedlings to be planted in afforestations is determined mostly based on the geographical conditions required 
for the growth of the species, and the plant length and root collar diameter are used as a basic element (Thompson, 1985). Changes in the growth of the root collar diameter and plant length of Cinnamomum yabunikkei depending on the concentration of the fertilizer were observed, and it was found that those grown in a container treated with a relatively low concentration of the fertilizer $\left(1.0 \mathrm{~g} \cdot \mathrm{L}^{-1}\right)$ showed the highest growth, and Neolitsea sericea grown in a container treated with the $1.5 \mathrm{~g} \cdot \mathrm{L}^{-1}$ concentration showed the highest growth. However, there was no statistically significant difference between different concentrations (Table 1). The relative growth rate of the plant length and root collar diameter was similar to their growth rate (except the growth results of the root collar diameter of Neolitsea sericea), and the H/D ratio also coincides with the growth results (Table 1). The higher the concentration of the fertilizer, the higher or lower the growth of the root collar diameter and length of each species, showing no statistically significant difference.

As shown in the results of this study, some earlier studies also reported that the higher the concentration of a fertilizer, the lower the growth of the root collar diameter and length of container-grown Betula pendula (Juntunen et al., 2003), Quercus myrsinaefolia Bl. (Sung et al., 2011), Betula costata Trautv. (Cho et al., 2011). In general, the growth and survival rates of plants increase as the concentration of a fertilizer increases, but after reaching a certain concentration level, they tend to decrease (Ingestad, 1979; Gilliam et al., 1980; Kwon et al., 2009). The level differs depending on the amount of nutrients required for each species, and the negative impact of excessive fertilization on the growth of plants seems to be nutrient toxicity (Timmer and Amstrong, 1987). In other words, since the different amount of nutrients is required for each species, it is necessary to suggest the optimal level of fertilization (drainage, recovery) for each species grown in bed soil in a greenhouse (Landis et al., 1989; Broschat, 1995; Dumroese et al., 2013).

Meanwhile, the growth of the root collar diameter and plant length of seedlings grown in the containers treated with the fertilizer were higher than that of those grown in the non-treated containers, which shows the importance of an optimal level of a fertilizer in the process of producing evergreen broad-leaved camphor trees like the species tested in this study.

Table 1. Root collar diameter (D), plant height $(H)$ and H/D ratio of container-grown seedlings of Neolitsea sericea and Cinnamomum yabunikkeiat different fertilization levels.

\begin{tabular}{|c|c|c|c|c|c|c|}
\hline \multirow{2}{*}{ Species } & \multirow{2}{*}{$\begin{array}{l}\text { Fertilization } \\
\left(\mathrm{g} \cdot \mathrm{L}^{-1}\right)\end{array}$} & \multicolumn{2}{|c|}{ Root collar diameter } & \multicolumn{2}{|c|}{ Height } & \multirow{2}{*}{$\begin{array}{l}\mathrm{H} / \mathrm{D} \text { ratio } \\
\left(\mathrm{cm} \cdot \mathrm{mm}^{-1}\right)\end{array}$} \\
\hline & & Growth (mm) & $\operatorname{RGR}^{z}\left(\mathrm{~mm} \cdot\right.$ day $\left.^{-1}\right)$ & Growth $(\mathrm{cm})$ & $\operatorname{RGR}^{\mathrm{z}}\left(\mathrm{cm} \cdot \mathrm{day}^{-1}\right)$ & \\
\hline \multirow{5}{*}{$\begin{array}{l}\text { Cinnamoтит } \\
\text { yabunikkei }\end{array}$} & 0.0 & $3.5 \pm 0.6^{y} c^{x}$ & $0.007 \pm 0.002 \mathrm{c}$ & $14.6 \pm 2.5 \mathrm{c}$ & $0.030 \pm 0.010 \mathrm{c}$ & $4.7 \pm 1.5 \mathrm{c}$ \\
\hline & 0.5 & $4.0 \pm 0.4 \mathrm{~b}$ & $0.010 \pm 0.002 \mathrm{ab}$ & $37.3 \pm 7.5 \mathrm{a}$ & $0.117 \pm 0.031 \mathrm{a}$ & $8.5 \pm 1.5 \mathrm{a}$ \\
\hline & 1.0 & $4.4 \pm 0.6 \mathrm{a}$ & $0.011 \pm 0.003 \mathrm{a}$ & $37.4 \pm 8.0 \mathrm{a}$ & $0.122 \pm 0.034 \mathrm{a}$ & $9.3 \pm 1.6 \mathrm{a}$ \\
\hline & 1.5 & $4.0 \pm 0.8 \mathrm{~b}$ & $0.009 \pm 0.004 \mathrm{~b}$ & $37.2 \pm 8.8 \mathrm{a}$ & $0.114 \pm 0.036 \mathrm{a}$ & $9.3 \pm 1.5 \mathrm{a}$ \\
\hline & 2.0 & $3.4 \pm 0.7 \mathrm{c}$ & $0.006 \pm 0.003 \mathrm{c}$ & $25.2 \pm 8.9 \mathrm{~b}$ & $0.062 \pm 0.033 b$ & $7.2 \pm 1.5 \mathrm{~b}$ \\
\hline \multirow{5}{*}{$\begin{array}{l}\text { Neolitsea } \\
\text { sericea }\end{array}$} & 0.0 & $2.8 \pm 0.4 \mathrm{c}$ & $0.006 \pm 0.001 \mathrm{~d}$ & $10.3 \pm 2.8 \mathrm{~b}$ & $0.024 \pm 0.009 \mathrm{~b}$ & $3.7 \pm 0.9 \mathrm{c}$ \\
\hline & 0.5 & $3.2 \pm 0.5 \mathrm{~b}$ & $0.008 \pm 0.002 \mathrm{c}$ & $22.4 \pm 4.2 \mathrm{a}$ & $0.071 \pm 0.019 \mathrm{a}$ & $6.9 \pm 1.0 \mathrm{a}$ \\
\hline & 1.0 & $3.5 \pm 0.4 \mathrm{a}$ & $0.009 \pm 0.002 \mathrm{bc}$ & $23.4 \pm 6.6 \mathrm{a}$ & $0.074 \pm 0.026 \mathrm{a}$ & $6.6 \pm 1.7 \mathrm{a}$ \\
\hline & 1.5 & $3.8 \pm 0.6 \mathrm{a}$ & $0.009 \pm 0.001 \mathrm{ab}$ & $26.5 \pm 3.1 \mathrm{a}$ & $0.080 \pm 0.018 \mathrm{a}$ & $7.0 \pm 1.0 \mathrm{a}$ \\
\hline & 2.0 & $3.6 \pm 0.3 \mathrm{a}$ & $0.010 \pm 0.003 \mathrm{a}$ & $22.1 \pm 6.3 \mathrm{a}$ & $0.070 \pm 0.027 \mathrm{a}$ & $5.8 \pm 1.1 \mathrm{~b}$ \\
\hline
\end{tabular}

${ }^{\mathrm{z}} \mathrm{RGR}$ : relative growth rate.

${ }^{\mathrm{y}} \mathrm{Mean} \pm \mathrm{SD}(\mathrm{n}=20)$.

${ }^{\mathrm{x}}$ Values with different letters within the columns indicate statistical differences at the $5 \%$ levels by Duncan's multiple range test. 


\section{H/D ratio}

The H/D ratio is a ratio of the above-ground growth to the below-ground growth and is used to evaluate the healthiness of seedlings (Deans et al., 1989). The healthiness of seedlings is evaluated based on the type of seedlings, for instance, whether they are stocky or spindly types (Thompson, 1985; Haase, 2007). The H/D ratio is useful for evaluating the ability of all kinds of seedlings either grown in an open field or in a container to tolerate physical damage such as wind and dryness, and, in some cases, it is used as an important criteria to evaluate container-grown spindly seedlings that grow well in high-density and low-light conditions, and thus have a high H/D ratio (Thompson, 1985; Haase, 2007). In addition, excess or deficiency in fertilizers can cause an imbalance between the above-ground growth and the below-ground growth, which results in negative effects after afforestation such as an increasing withering rate, and a decreasing growth rate (Etter, 1971; Phillion and Libby, 1984; Van den Driessche, 1988).

In this study, changes in the H/D ratio of Neolitsea sericea and Cinnamomum yabunikkei seedlings grown in containers treated with the different concentrations of a fertilizer were examined. The ratio of Neolitsea sericea seedlings in the 1.5 $\mathrm{g} \cdot \mathrm{L}^{-1}$ container was the highest $\left(7.0 \mathrm{~cm} \cdot \mathrm{mm}^{-1}\right)$, and that of those in the non-treated containers, the lowest $\left(3.7 \mathrm{~cm} \cdot \mathrm{mm}^{-1}\right)$. The H/D ratio of Cinnamomum yabunikkei seedlings in the $1.0 \mathrm{~g} \cdot \mathrm{L}^{-1}$ container was the highest $\left(9.3 \mathrm{~cm} \cdot \mathrm{mm}^{-1}\right)$, and that of those in the non-treated container, the lowest $\left(4.7 \mathrm{~cm} \cdot \mathrm{mm}^{-1}\right)$. Regardless of the concentrations of the fertilizer, the H/D ratio of Neolitsea sericea ranged from 3.7 to $7.0 \mathrm{~cm} \cdot \mathrm{mm}^{-1}$, and that of Cinnamomum yabunikkei ranged from 4.7 to 9.3 $\mathrm{cm} \cdot \mathrm{mm}^{-1}$. Johnson et al. (1996) reported that container-grown seedlings of which H/D ratio is lower than $10 \mathrm{~cm} \cdot \mathrm{mm}^{-1} \mathrm{can}$ be categorized as a healthy seedling. Guidelines for seed and nursery businesses in Korea suggest the standards of seedlings for forests, and the standard H/D ratio of needle-leaved trees ranges from 8 to $14 \mathrm{~cm} \cdot \mathrm{mm}^{-1}$, and that of broad-leaved trees ranges from 9 to $22 \mathrm{~cm} \cdot \mathrm{mm}^{-1}$ (KFS, 2013).

In this study, both of the two species showed a statistically significant change in the H/D ratio depending on the concentration of a fertilizer, but the ratio was lower than the range suggested in the guidelines for seed and nursery businesses, which is attributable to differences in the conditions for the growth of each species such as different concentrations of the fertilizer and watering techniques or differences in the growth reaction of each species. However, since the growth patterns and the characteristics of each species differ, it is difficult to evaluate the quality of their seedlings and identify the proper amount of a fertilizer for each species based on one element, such as the H/D ratio. It is recommended to comprehensively consider their growth characteristics such as the distribution of photosynthates and the development of roots, and their physiological characteristics such as photosynthesis and chlorophyll content.

\section{Dry weight}

The dry weight of seedlings is closely related to their root collar diameter, and the two elements are recognized as a key factor that affects their survival and growth rates after afforestation (Switzer and Nelson, 1963; Ritchie, 1984). In this study, the balanced growth of seedlings grown in containers treated with the different concentrations of a fertilizer was examined by measuring the dry weight of above-ground and below-ground parts. The dry weight of each part and the entire body was measured, and it was found that the dry weight of the leaves, stems, roots and entire body of seedlings grown in the non-treated container was lower than that of those grown in containers treated with the different concentrations of the fertilizer (Table 2). Neolitsea sericea seedlings in the $1.5 \mathrm{~g} \cdot \mathrm{L}^{-1}$ container showed significantly the highest total dry weight, over $30 \%$ higher than that of seedlings in the non-treated container. The total dry weight of Cinnamomum yabunikkei seedlings in the $1.0 \mathrm{~g} \cdot \mathrm{L}^{-1}$ container was the highest, over $34 \%$ higher than that of seedlings in the non-treated container, but there was no statistically significant difference between different concentrations. The total dry weight of the two species tended to decrease when the concentration of the fertilizer was higher than $1.5 \mathrm{~g} \cdot \mathrm{L}^{-1}$ as the results of the root 
Table 2. The effect of five different fertilization levels on the biomass production and T/R ratio of container-grown seedlings of Neolitsea sericea and Cinnamomum yabunikkei.

\begin{tabular}{|c|c|c|c|c|c|c|}
\hline \multirow{2}{*}{ Species } & \multirow{2}{*}{$\begin{array}{c}\text { Fertilization } \\
\left(\mathrm{g} \cdot \mathrm{L}^{-1}\right)\end{array}$} & \multicolumn{4}{|c|}{ Dry weight (g) } & \multirow{2}{*}{$\begin{array}{c}\mathrm{T} / \mathrm{R} \text { ratio } \\
\left(\mathrm{g} \cdot \mathrm{g}^{-1}\right)\end{array}$} \\
\hline & & Leaf & Stem & Root & Total & \\
\hline \multirow{5}{*}{$\begin{array}{l}\text { Cinnamoтum } \\
\text { yabunikkei }\end{array}$} & 0.0 & $1.05 \pm 0.33^{z} d^{y}$ & $0.40 \pm 0.10 \mathrm{c}$ & $0.58 \pm 0.19 \mathrm{c}$ & $2.04 \pm 0.47 \mathrm{~d}$ & $2.50 \pm 0.20 \mathrm{a}$ \\
\hline & 0.5 & $2.08 \pm 0.32 \mathrm{c}$ & $1.05 \pm 0.19 \mathrm{~b}$ & $1.06 \pm 0.30 \mathrm{~b}$ & $4.18 \pm 0.71 \mathrm{c}$ & $2.95 \pm 0.08 \mathrm{a}$ \\
\hline & 1.0 & $3.11 \pm 0.92 \mathrm{a}$ & $1.45 \pm 0.21 \mathrm{a}$ & $1.45 \pm 0.32 \mathrm{a}$ & $6.01 \pm 0.25 \mathrm{a}$ & $3.14 \pm 0.04 \mathrm{a}$ \\
\hline & 1.5 & $2.71 \pm 0.56 \mathrm{ab}$ & $1.37 \pm 0.36 \mathrm{a}$ & $1.39 \pm 0.24 \mathrm{a}$ & $5.47 \pm 0.89 \mathrm{ab}$ & $2.94 \pm 0.42 \mathrm{a}$ \\
\hline & 2.0 & $2.46 \pm 0.37 \mathrm{bc}$ & $1.31 \pm 0.24 \mathrm{a}$ & $1.11 \pm 0.33 b$ & $4.88 \pm 0.53 b c$ & $3.40 \pm 0.17 \mathrm{a}$ \\
\hline \multirow{5}{*}{$\begin{array}{l}\text { Neolitsea } \\
\text { sericea }\end{array}$} & 0.0 & $0.57 \pm 0.10 \mathrm{a}$ & $0.33 \pm 0.07 \mathrm{~d}$ & $0.72 \pm 0.06 \mathrm{c}$ & $1.62 \pm 0.35 \mathrm{~d}$ & $1.25 \pm 0.13 \mathrm{c}$ \\
\hline & 0.5 & $0.94 \pm 0.03 \mathrm{c}$ & $0.81 \pm 0.19 \mathrm{c}$ & $0.94 \pm 0.34 \mathrm{c}$ & $3.18 \pm 0.76 \mathrm{c}$ & $1.86 \pm 0.08 \mathrm{~b}$ \\
\hline & 1.0 & $1.34 \pm 0,23 \mathrm{c}$ & $0.80 \pm 0.21 \mathrm{c}$ & $1.03 \pm 0.02 b c$ & $3.17 \pm 0.49 \mathrm{c}$ & $2.08 \pm 0.14 \mathrm{ab}$ \\
\hline & 1.5 & $1.54 \pm 0.50 \mathrm{a}$ & $1.70 \pm 0.65 \mathrm{a}$ & $1.54 \pm 0.50 \mathrm{a}$ & $5.92 \pm 1.30 \mathrm{a}$ & $2.10 \pm 0.09 \mathrm{a}$ \\
\hline & 2.0 & $1.34 \pm 0.42 \mathrm{~b}$ & $1.15 \pm 0.16 \mathrm{~b}$ & $1.34 \pm 0.42 \mathrm{ab}$ & $4.36 \pm 0.74 \mathrm{~b}$ & $1.86 \pm 0.07 \mathrm{ab}$ \\
\hline
\end{tabular}

${ }^{\mathrm{z}}$ Values are means of 20 replicates \pm SD.

${ }^{\mathrm{y}}$ Values with different letters within the columns indicate statistical differences at the $5 \%$ levels by Duncan's multiple range test.

collar diameter and plant length of the two species showed.

Proper fertilization that meets the amount of nutrients required for each species creates optimal nutritional conditions in soil, which results in significant growth combined with active photosynthesis activities (Richards et al., 1973; Han and Chiba 2009; Cho et al., 2011). In particular, the nutrient content in soil is in a proportional relationship with the growth of plants (Inagaki et al., 2009). In addition, fertilization affects the content of organic matters, the characteristics of microorganisms, the activity of enzymes, etc., which, in turn, affects the growth characteristics of plants (Compton et al., 2004). In this study, seedlings of both the two species that showed a relatively high root collar diameter and plant length also showed a high dry weight, and in many earlier studies, seedlings that showed a high root collar diameter and plant length and good physiological characteristics depending on the type, method and timing of drainage, and the type of fertilizers also showed the highest dry weight and nutrient use efficiency (Timmer and Miller, 1991; Juntunen et al., 2003; Way et al., 2007; Kwon et al., 2009; Luis et al., 2009; Park et al., 2010; Cho et al., 2012; Dumroese et al., 2013).

Water soluble fertilizers used in greenhouses are mostly composed of nitrogen, phosphorus, potassium and other microelements, and these nutrients affect the growth of plants (Ingestad and Agren, 1992). In other words, the higher the amount of fertilizers, the more sufficiently plants can absorb nutrients, which addresses a deficiency in nutrients and increases the growth of plants (Salifu and Jacobs, 2006). In general, the higher the amount of fertilizers, the higher the growth rate of plants, but some species can be damaged by excessive fertilization beyond their critical concentration (Landis et al., 1989; Park et al., 2013). Teng and Timmer (1995) reported that the growth of Abies holophylla trees decreased due to the increasing acidity in soil and aluminium toxicity caused by applying nitrogen fertilizers excessively beyond the proper level. In this study, Cinnamomum yabunikkei and Neolitsea sericea also sensitively responded to the concentrations of a fertilizer, showing damage caused by excessive fertilization.

\section{T/R ratio and seedling quality index (SQI)}

The $\mathrm{T} / \mathrm{R}$ ratio is an seedling quality index (SQI) that has been widely used to measure a balance between the 
above-ground parts that transpire and the below-ground parts that absorb water (Haase, 2007). However, it is still controversial to determine the quality of seedlings based on the T/R ratio only (Thompson, 1985). Seedlings with a high dry weight of the above-ground parts and a high T/R ratio show a lower resistance against moisture stress after afforestation and thus poor afforestation performances. In this study, however, the T/R ratio of Cinnamomum yabunikkei seedlings in the non-treated container was the lowest $\left(2.50 \mathrm{~g} \cdot \mathrm{g}^{-1}\right)$, and those in the $1.0 \mathrm{~g} \cdot \mathrm{L}^{-1}$ container was the highest $\left(3.14 \mathrm{~g} \cdot \mathrm{g}^{-1}\right)$. The T/R ratio of Neolitsea sericea seedlings in the non-treated container was the lowest $\left(1.25 \mathrm{~g} \cdot \mathrm{g}^{-1}\right)$, and those in the $1.5 \mathrm{~g} \cdot \mathrm{L}^{-1}$ container was the highest $\left(2.10 \mathrm{~g} \cdot \mathrm{g}^{-1}\right)$. The $\mathrm{T} / \mathrm{R}$ ratio of those grown in treated containers was relatively higher, which is attributable to the fact that active photosynthesis activities under sufficient nutritional conditions increase the growth of the below-ground parts. These results coincide with those of Cho et al. (2012) on the growth characteristics of broad-leaved seedlings in containers treated with the different concentrations of a fertilizer, and since the T/R ratio of seedlings in all the treated containers was slightly lower or higher than $3.0 \mathrm{~g} \cdot \mathrm{g}^{-1}$, which was a tolerable level.

Meanwhile, Haase (2007) reported that for seedlings grown in open fields the T/R ratio needs to be 3.0 or slightly lower than that. Those with the T/R ratio ranging from 2.5 to 3.0 can be recognized as a healthy seedling in Korea, similar to the range of other countries. The recommended $\mathrm{T} / \mathrm{R}$ ratio was compared with the results of this study, and those grown in treated containers which showed a relatively high plant length and root collar diameter and a high dry weight were also found to have a relatively high T/R ratio. It was found that the $1.5 \mathrm{~g} \cdot \mathrm{L}^{-1}$ and $1.0 \mathrm{~g} \cdot \mathrm{L}^{-1}$ concentrations of a fertilizer are suitable for producing 3-year old container-grown Neolitsea sericea and Cinnamomum yabunikkei seedlings respectively. Seedlings grown in containers treated with a proper amount of a fertilizer have a high photosynthetic capacity and also show high growth and survival rates after afforestation (Leiva and Fernandez-Ales, 1998; Oliet et al., 2009). This is attributable to the fact that a proper amount of a fertilizer increases the capacity of roots to absorb and transport water (Chirino et al., 2008; Trubat et al., 2008; Hernandez et al., 2009). The high-quality seedlings produced through the proper fertilization process are expected to show better afforestation performances.

The seedling quality index (SQI) showed a statistically significant difference between the different concentrations of a fertilizer, and the SQI of Neolitsea sericea seedlings in the $1.5 \mathrm{~g} \cdot \mathrm{L}^{-1}$ container was the highest $(0.79)$. and that of Cinnamomum yabunikkei seedlings in the $1.0 \mathrm{~g} \cdot \mathrm{L}^{-1}$ container was the highest (0.77) (Fig. 1). Whereas, the SQI of

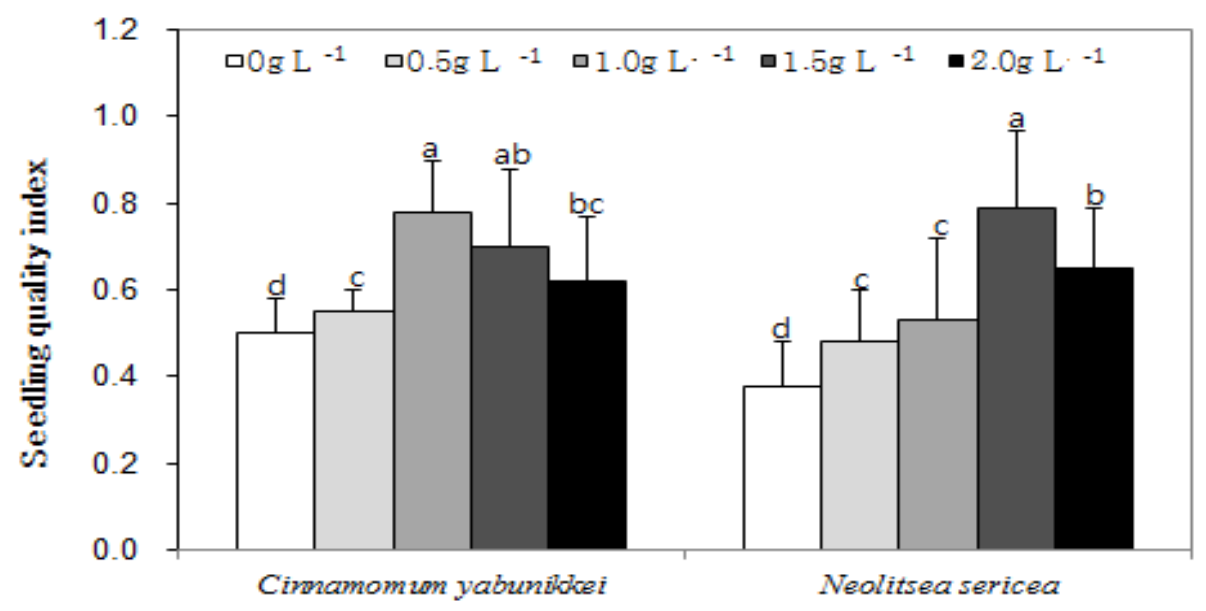

Figure 1. The effect of five different fertilization levels on seedling quality index of container-grown seedlings of Neolitsea sericea and Cinnamomum yabunikkei. Vertical bars represent SD of the mean $(n=10)$. Different letters within a species show statistical differences among fertilization treatments at the $5 \%$ levels by Duncan's multiple range test. 
seedlings of both of the two species in the $2.0 \mathrm{~g} \cdot \mathrm{L}^{-1}$ container decreased to 0.66 (Neolitsea sericea), and 0.63 (Cinnamomum yabunikkei), which coincides with the results of the root collar diameter, plant length and dry weight. This indicates that when the above-ground and below-ground parts grow in a balanced way, not only the physiological and growth characteristics of seedlings but also their quality can be improved.

Based on these results, it can be concluded that changes in the nutritional conditions of seedlings in containers depending on the concentration of a fertilizer in greenhouses are very closely related to the quality and productivity of seedlings, and that proper fertilization results in high-quality seedlings, and, in turn, better performances after afforestation. In addition, it is possible to reduce environmental pollution near seedling nurseries by minimizing the content of fertilizers in leachate, and to shorten the period for cultivating seedlings, providing economic benefits.

\section{Physiological characteristics}

\section{Chlorophyll fluorescence reaction}

The photochemical efficiency of seedlings depending on the concentration of a fertilizer was analyzed by measuring the maximum net apparent quantum yield, and that of Neolitsea sericea seedlings in the $1.5 \mathrm{~g} \cdot \mathrm{L}^{-1}$ container was the highest and that of those in the non-treated container, the lowest, showing a statistically significant difference. The photochemical efficiency of Cinnamomum yabunikkei seedlings in the $1.0 \mathrm{~g} \cdot \mathrm{L}^{-1}$ container was the highest, and as the concentration increases, the photochemical efficiency tended to decrease (Fig. 2). Photochemical efficiency is an important indicator of stress on growth environments (Rascher et al., 2000), and is closely related to the photosynthesis capacity of plants (Bose et al., 1988). Photochemical efficiency is in a proportional relationship with photosynthesis capacity. The photochemical efficiency of healthy leaves is around 0.83 (Krause and Weis, 1991), but, in this study, that of the two species was lower than the level. This results is attributable to the fact that seedlings, 3 months after being transplanted from containers, are also sensitive to other growth environments such as light, temperature, moisture, etc.

\section{Chlorophyll content}

The photopigment content in leaves tends to decrease under stress, and thus it has been widely used as an indicator of

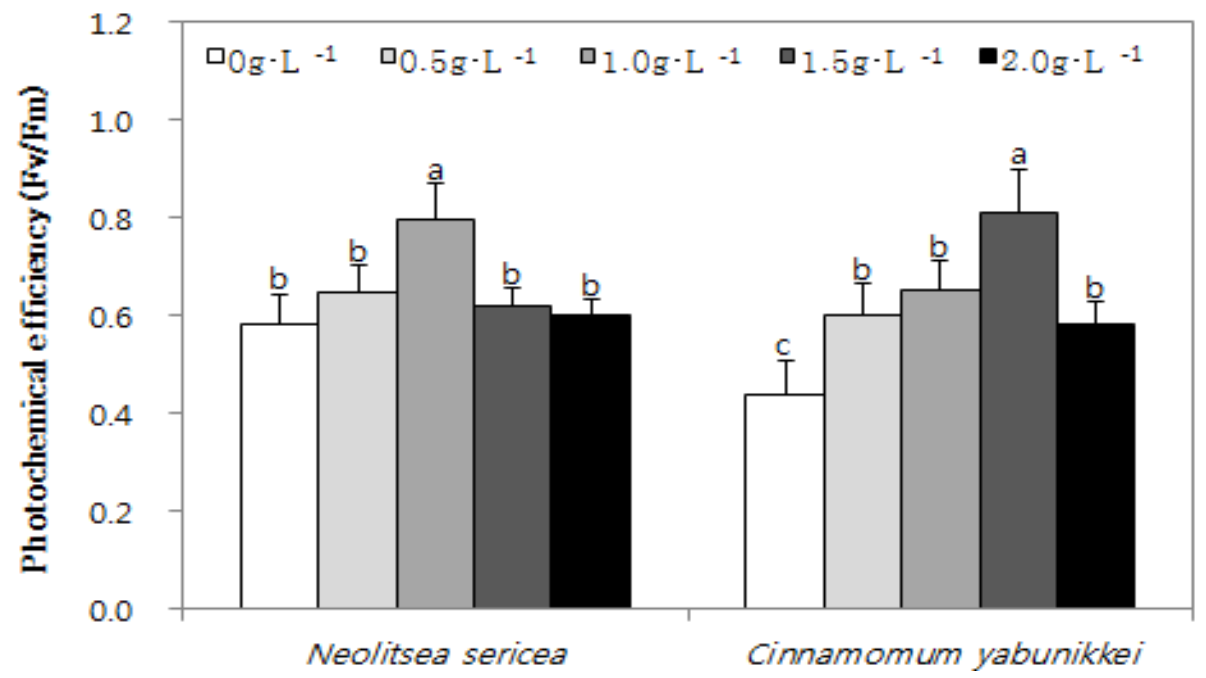

Figure 2. The effect of five different fertilization levels on photochemical efficiency of container-grown seedlings of Neolitsea sericea and Cinnamomum yabunikkei. Vertical bars represent SD of the mean $(n=10)$. Different letters within a species show statistical differences among fertilization treatments at the $5 \%$ levels by Duncan's multiple range test. 
stress, showing a big difference between species (Han et al., 2009; Kim et al., 2001). Changes in chlorophyll a, chlorophyll $\mathrm{b}$, total chlorophyll content and $\mathrm{a} / \mathrm{b}$ ratio depending on the concentration of a fertilizer were measured. Neolitsea sericea seedlings showed a statistically significant difference in chlorophyll a, chlorophyll b, and total chlorophyll content, and those grown in the $1.5 \mathrm{~g} \cdot \mathrm{L}^{-1}$ container showed the highest chlorophyll content (Table 3). Cinnamomum yabunikkei seedlings grown in the $1.0 \mathrm{~g} \cdot \mathrm{L}^{-1}$ container showed the highest chlorophyll content, which coincides with the results of photochemical efficiency. The $\mathrm{a} / \mathrm{b}$ ratio of seedlings grown in the treated containers was higher than that of seedlings grown in the non-treated container, which indicates that the growth rate of chlorophyll a in the treated containers was higher than that of chlorophyll $\mathrm{b}$. The photosynthesis capacity of plants is very closely related to nitrogen content (Kim and Lee, 2001), and this is because over $70 \%$ of the nitrogen content in leaves forms proteins related to photosynthesis (Hikosaka and Terashima, 1995). In other words, excess or deficiency in nutrients caused by fertilizers can reduce the photosynthesis capacity of plants in greenhouses, and affect the creation of chlorophyll that is very closely related to photosynthesis activities (Cho et al., 2012). The chlorophyll content in seedlings in the treated containers was higher than that in seedlings in the non-treated container, which coincides with the results of the growth characteristics.

The chlorophyll fluorescence reaction and content results indicate that fertilization affects the capacity of plants to secure light in the light reaction process in greenhouses (Kwon et al., 2009). Fertilization is related to the photosynthesis and growth activities of plants, and thus significantly affects the production and quality of seedlings in the process of cultivating them (Cho et al., 2012). In addition, seedlings grown in containers treated with a proper amount of a fertilizer have a high photosynthetic capacity and also show high growth and survival rates after afforestation (Leiva and Fernandez-Ales, 1998; Oliet et al., 2009). This is attributable to the fact that a proper amount of a fertilizer increases the capacity of roots to absorb and transport water (Chirino et al., 2008). Considering this process, a proper amount of a fertilizer for Neolitsea sericea and Cinnamomum yabunikkei seedlings for healthy growth are found to be $1.5 \mathrm{~g} \cdot \mathrm{L}^{-1}$ and 1.0 $\mathrm{g} \cdot \mathrm{L}^{-1}$ respectively, which is also expected to improve the performances of afforestation.

Table 3. The effect of fertilization level on chlorophyll content of container-grown seedlings of Neolitsea sericea and Cinnamomum yabunikkei.

\begin{tabular}{|c|c|c|c|c|c|}
\hline \multirow{2}{*}{ Species } & \multirow{2}{*}{$\begin{array}{l}\text { Fertilization } \\
\qquad\left(\mathrm{g} \cdot \mathrm{L}^{-1}\right)\end{array}$} & \multicolumn{3}{|c|}{ Chlorophyll content $\left(\mathrm{mg} \cdot \mathrm{g}^{-1}\right.$ fresh weight) } & \multirow{2}{*}{ Chl. a/b } \\
\hline & & Chl. a & Chl. b & Total Chl. & \\
\hline \multirow{5}{*}{$\begin{array}{l}\text { Cinnamomum } \\
\text { yabunikkei }\end{array}$} & 0.0 & $7.14 \pm 0.33^{\mathrm{z}} \mathrm{d}^{\mathrm{y}}$ & $4.69 \pm 0.45 \mathrm{c}$ & $11.84 \pm 0.80 \mathrm{c}$ & $1.03 \pm 0.87 \mathrm{a}$ \\
\hline & 0.5 & $7.75 \pm 0.33 \mathrm{~cd}$ & $7.55 \pm 0.17 \mathrm{a}$ & $15.31 \pm 0.28 b$ & $1.65 \pm 0.14 b$ \\
\hline & 1.0 & $12.93 \pm 0.23 \mathrm{a}$ & $8.04 \pm 0.84 \mathrm{a}$ & $20.97 \pm 0.04 \mathrm{a}$ & $1.71 \pm 0.70 \mathrm{a}$ \\
\hline & 1.5 & $10.00 \pm 0.35 b$ & $6.85 \pm 0.47 \mathrm{ab}$ & $16.85 \pm 0.62 b$ & $1.53 \pm 0.39 \mathrm{ab}$ \\
\hline & 2.0 & $9.12 \pm 0.41 b c$ & $6.11 \pm 0.59 b$ & $15.23 \pm 0.89 b$ & $1.50 \pm 0.12 \mathrm{ab}$ \\
\hline \multirow{5}{*}{$\begin{array}{l}\text { Neolitsea } \\
\text { sericea }\end{array}$} & 0.0 & $9.23 \pm 0.79 \mathrm{~d}$ & $1.45 \pm 0.60 \mathrm{c}$ & $10.68 \pm 1.39 \mathrm{~d}$ & $5.67 \pm 0.21 \mathrm{a}$ \\
\hline & 0.5 & $11.52 \pm 0.78 \mathrm{~cd}$ & $2.09 \pm 0.32 \mathrm{c}$ & $13.60 \pm 1.10 \mathrm{~cd}$ & $5.61 \pm 0.24 \mathrm{a}$ \\
\hline & 1.0 & $12.18 \pm 0.97 \mathrm{c}$ & $2.17 \pm 0.29 \mathrm{c}$ & $14.46 \pm 1.26 \mathrm{c}$ & $6.24 \pm 0.23 \mathrm{a}$ \\
\hline & 1.5 & $25.72 \pm 0.72 \mathrm{a}$ & $4.24 \pm 0.80 \mathrm{a}$ & $30.03 \pm 1.52 \mathrm{a}$ & $6.24 \pm 0.94 \mathrm{a}$ \\
\hline & 2.0 & $19.86 \pm 0.92 b$ & $3.29 \pm 0.48 b$ & $23.15 \pm 1.40 \mathrm{~b}$ & $6.09 \pm 0.49 \mathrm{a}$ \\
\hline
\end{tabular}

${ }^{\mathrm{z}}$ Values are means of 20 replicates \pm SD.

${ }^{\mathrm{y}}$ Values with different letters within the columns indicate statistical differences at the $5 \%$ levels by Duncan's multiple range test. 


\section{Conclusions}

This study aimed to examine and analyze the growth characteristics of seedlings, grown in containers treated with a water soluble compound fertilizer (N:P:K=19:19:19, v/v/v), including root collar diameter, plant length, dry weight and seedling quality index (SQI), and their physiological characteristics, including photochemical efficiency and chlorophyll content, and to identify a proper amount of a fertilizer for each species. Two broad-leaved plants that are widely used for afforestation (Cinnamomum yabunikkei and Neolitsea sericea) were used in this study. The growth characteristics of seedlings depending on the concentration of the fertilizer were analyzed first, and Neolitsea sericea seedlings in the 1.5 $\mathrm{g} \cdot \mathrm{L}^{-1}$ container, and Cinnamomum yabunikkei seedlings in the $1.0 \mathrm{~g} \cdot \mathrm{L}^{-1}$ container showed the highest root collar diameter and plant length. The H/D ratio of those that showed the highest root collar diameter and plant length was calculated, and that of Neolitsea sericea and Cinnamomum yabunikkei was $7.0 \mathrm{~cm} \cdot \mathrm{mm}^{-1}$ and $9.3 \mathrm{~cm} \cdot \mathrm{mm}^{-1}$ respectively, which was statistically significantly higher than those grown in other containers. The dry weight of Neolitsea sericea seedlings grown in the $1.5 \mathrm{~g} \cdot \mathrm{L}^{-1}$ container was the highest $(5.92 \mathrm{~g})$, and that of Cinnamomum yabunikkei seedlings grown in the $1.0 \mathrm{~g} \cdot \mathrm{L}^{-1}$ container was the highest $(6.01 \mathrm{~g})$. Seedlings with a high dry weight also showed a statistically significantly high $\mathrm{T} / \mathrm{R}$ ratio and SQI. The physiological characteristics of seedlings depending on the concentration of the fertilizer were also analyzed, and the chlorophyll fluorescence reaction and content of seedlings of the two species grown in the non-treated containers were low. Neolitsea sericea seedlings in the $1.5 \mathrm{~g} \cdot \mathrm{L}^{-1}$ container, and Cinnamomum yabunikkei seedlings in the $1.0 \mathrm{~g} \cdot \mathrm{L}^{-1}$ container showed a high chlorophyll fluorescence reaction and content. Based on the results of this study, it can be concluded that a proper fertilization level differs depending on the amount of nutrients required for each species, and that the $1.5 \mathrm{~g} \cdot \mathrm{L}^{-1}$ and $1.0 \mathrm{~g} \cdot \mathrm{L}^{-1}$ concentrations of a water soluble fertilizer are suitable for producing 2-year old container-grown Neolitsea sericea and Cinnamomum yabunikkei seedlings that have a high growth rate and SQI, respectively. However, since 2-year old young seedlings were used in this study and short-term reactions to the different concentrations of a fertilizer were analyzed only, it is difficult to predict their long-term reactions based on the results. In addition, seedlings are mostly produced in greenhouses or nursery fields, and it is necessary to conduct additional studies on the reactions of plants to rapidly changing climate conditions in the future. Since the reactions of each species to the different concentrations of a fertilizer significantly differs, it is also necessary to continuously conduct studies on more species that are widely used in Korea and are sensitive to climate change.

\section{References}

Aghai, M.M., J.R. Pinto, and A.S. Davis. 2014. Container volume and growing density influence western larch (Larix occidentalis Nutt.) seedling development during nursery culture and establishment. New For. 45(2):199-213. DOI: 10.1007/s11056-013-9402-8

Bayala, J. M.Dianda, J. Wilson, S.J Ouedraogo, and K. Sanon. 2009. Predicting field performance of five irrigated tree species using seedling quality assessment in Burkina Faso, West Africa. New For. 38(3):309-322. DOI: 10.1007/ s11056-009-9149-4

Bose, S., S.K. Herbert, and D.C. Fork. 1988. Fluorescence characteristics of photo-inhibition and recovery in a sun and a shade species of the red algal genus Porphyra. Plant Physiol. 86(3):946-950. DOI: 10.1104/pp.86.3.946

Broschat, T.K. 1995. Nitrate, phosphate, and potassium leaching from container-grown plants fertilized by several methods. Hortscience. 30(1):74-77.

Byun, J.K., Y.S. Kim, M.J. Yi, Y.H. Son, C.S. Kim, J.H. Jeong, C.Y. Lee, and Y.H. Jeong. 2007. Growth response of Pinus densiflora, Larix leptolepis, Betula platyphylla var. japonica and Quercus acutissima seedlings at various levels of 
fertilization. J. Korean For. Soc. 96(6):693-698.

Chirino, E., A. Vilagrosa, E.I. Hernandez, A. Matos, and V.R. Vallejo. 2008. Effects of a deep container on morphofunctional characteristics and root colonization in Quercus suber L. seedlings for reforestation in Mediterranean climate. For. Ecol. Manag. 256(4):779-785. DOI:10.1016/j.foreco.2008.05.035

Cho, M.S., S.W. Lee, B.B. Park, and G.S. Park. 2011. The effects of fertilization on growth performances and physiological characteristics of Liriodendron tulipifera in a container nursery system. J. Korean For. Soc. 100(2):305-313.

Cho, M.S., S.W. Lee, and B.B. Park. 2012. Effects of fertilization methods on the growth and physiological characteristics of Larix kaempferi seedlings in the container nursery system. Prot. Hort. Plant Fact. 21(1):57-65.

Choi, Y.B. and J.H. Kim. 1995. Change in needle chlorophyll fluorescence of Pinus densiflora and Pinus thunbergii treated with artificial acid rain. J. Korean For. Soc. 84(1):97-102.

Compton, J., L.S. Watrud, L.A. Porteus, and S. DeGrood. 2004. Response of soil microbial biomass and community composition to chronic nitrogen additions at Harvard forest. For. Ecol. Manag. 196(1):143-158. DOI:10.1016/ j.foreco.2004.03.017

Deans, J.D., W.L. Mason, M.G.R. Cannell, A.L. Sharpe, and L.J. Sheppard. 1989. Growing regimes for bare-root stock of sitka spruce, douglas fir and scots pine. 1. Morphology at the end of the nursery phase. Forestry 62:53-60.

Demmig, B. and O. Bjorkman. 1987. Comparison of the effect of excessive light on chlorophyll fluorescence (77K) and photon yield of O2 evolution in leaves of higher plants. Planta 171(2):171-184. DOI:10.1007/BF00391092

Dominguez-Lerena, S., N.H. Sierra, I.C. Manzano, L.O. Bueno, J.L.P. Rubira, and J.G. Mexal. 2006. Container characteristics influence Pinus pinea seedling development in the nursery and field. For. Ecol. Manag. 221(1-3):63-71. DOI:10.1016/ j.foreco.2005.08.031

Dumroese, R.K., D.S. Page-Dumroese, K.F. Salifu, and D.F. Jacobs. 2013. Exponential fertilization of Pinus monticola seedlings: Nutrient uptake efficiency, leaching fractions, and early outplanting performance. Can. J. For. Res. 35(12): 2961-2967. DOI:10.1139/x05-226

Etter, H.M. 1971. Nitrogen and phosphorus requirements during the early growth of white spruce seedlings. Can. J. Plant Sci. 51:61-63.

Gilliam, C.H., S.M. Still, S. Moor, and M.E. Watson. 1980. Effects of three nitrogen levels on container-grown Acer rubrum. HortScience 15(5):641-642.

Grossnickle, S.C. 2005. Importance of root growth in overcoming planting stress. New For. 30(2-3):273-294. DOI: 10.1007/s11056-004-8303-2

Han, Q. and Y. Chiba. 2009. Leaf photosynthetic responses and related nitrogen changes associated with crown reclosure after thinning in a young Chamaecyparis obtusa stand. J. For. Res. 14(6):349-357. DOI:10.1007/s10310-009-0146-4

Haase, D.L. 2007. Morphological and physiological evaluation of seedling quality. p. 3-8. In: L.E. Riley, R.K. Dumroese, and T.D. Landes (eds.). Proceedings of the conference "Forest and Conservation Nursery Associations- 2006", RMRS-P-50, USDA Forest Service, Rocky Mountain Research Station, Fort Collins, CO, USA.

Hernandez, E.I., A. Vilagrosa, V.C. Luis, M. Llorca, E. Chirino, and V.R. Vallejo. 2009. Root hydraulic conductance, gas exchange and leaf water potential in seedlings of Pistacia lentiscus L. and Quercus suber L. grown under different fertilization and light regimes. Environ. Exp. Bot. 67(1):269-276. DOI:10.1016/j.envexpbot.2009.07.004

Hikosaka, K. and I. Terashima. 1995. A model of the acclimation of photosynthesis in the leaves of C3 plants to sun and shade with respect to nitrogen uses. Plant Cell Environ. 18:605-618.DOI: 10.1111/j.1365-3040.1995.tb00562.x

Hiscox, J.D. and G.F. Israelastam. 1979. A method for the extraction of chlorophyll from leaf tissue without maceration. Can. J. Bot. 57(12):1332-1334. DOI: 10.1139/b79-163

Hughes, A.P. and P.R. Freeman. 1967. Growth analysis using frequent small harvests. J. Appl. Ecol. 4(2):553-560. DOI: $10.2307 / 2401356$

Ingestad, T. 1979. Mineral nutrient requirement of Pinus silvestris and Picea abies seedlings. Physiol. Plant. 45(4):373-380. DOI: 10.1111/j.1399-3054.1979.tb02599.x 
Ingestad, T. and G.I. Agren. 1992. Theories and methods on plant nutrition and growth. Physiol. Plant. 84:177-184. DOI: 10.1111/j.1399-3054.1992.tb08781.x

Inagaki, M., Y. Inagaki, K. Kamo, and J. Titin. 2009. Fine root production in response to nutrient application at three forest plantations in Sabah, Malaysia: Higher nitrogen and phosphorus demand by Acacia mangium. J. For. Res. 14(3): 178-182. DOI: 10.1007/s10310-009-0113-0

Johnson, F., L. Paterson, G. Leeder, C. Mansfield, F. Pinto, and S. Watson. 1996. Artificial regeneration of Ontario's forest: Species and stock selection manual. (No. 131). Sault Ste. Marie: Ontario Ministry of Natural Resources.

Juntunen, M.L., T. Hammar, and R. Rikala. 2003. Nitrogen and phosphorus leaching and uptake by container birch seedlings (Betula pendula Roth) grown in three different fertilizations. New For. 25(2):133-147.

Kim, P.G. and E.J. Lee. 2001. Ecophysiology of photosynthesis 1: Effects of light intensity and intercellular $\mathrm{CO}_{2}$ pressure on photosynthesis. Korean J. Agric. For. Meteorol. 3(2):126-133.

Kim, J.J., K.J. Lee, K.S. Song, Y.G Cha, Y.S. Chung, J.H Lee, and T.S. Yoon. 2010. Exploration of optimum container for production of Larix leptolepsis container seedlings. J. Korean For. Soc. 99(4):638-644.

KFS (Korea Forest Service). 2013. Actual results of afforestation in 2012. Retrieved from http://dlps.nanet.go.kr/ DlibViewer.do?cn=MONO1201246134\&sysid=nhn

Krause, G.H. and E. Weis. 1991. Chlorophyll fluorescence and photosynthesis: The basics. Annu. Rev. Plant Physiol. Plant Mol. Biol. 42:313-349. DOI: 10.1146/annurev.pp.42.060191.001525

Kwon, K.W., M.S. Cho, G.N. Kim, S.W. Lee, and K.H. Jang. 2009. Photosynthetic characteristics and growth performances of containerized seedling and bare root seedling of Quercus acutissima growing at different fertilizing schemes. J. Korean For. Soc. 98(3):331-338.

Landis, T.D., R.W. Tinus, S.E. McDonald, and J.P. Barnett. 1989. The container tree nursery manual: seedling nutrition and irrigation (No. 674). United States Government Printing.

Landis, T.D., R.W. Tinus, S.E. McDonald, and J.P. Barnett. 1995. Container tree nursery manuals vol.1: Nursery planning, development, and management. Portlant, USA: Western Forestry \& Conservation Association.

Lee, C.H., C.H. Shin, K.S. Kim, and M.S. Choi. 2006. Effects of light intensity on photosynthesis and growth in seedling of Kalopanax pictus Nakai. Korean J. Med. Crop Sci. 14(4):244-249.

Leiva, M.J. and R. Fernandez-Ales. 1998. Variability in seedling water status during drought within a Quercus ilex subsp. ballota population, and its relation to seedling morphology. For. Ecol. Manag. 111(2-3):147-156. DOI: 10.1016/ S0378-1127(98)00320-X

Luis, W.C., J. Puertolas, J. Climent, J. Peters, A.M. Gonzalez Rodriguez, D. Morales, and M.S. Jimenez. 2009. Nursery fertilization enhances survival and physiological status in Canary Island pine (Pinus canariensis) seedlings planted in a semiarid environment. Eur. J. For. Res. 128(3)221-229. DOI: 10.1007/s10342-009-0257-7

Oliet, J., R. Planelles, F. Artero, R. Valverde, D.F. Jacobs, and M.L. Segura. 2009. Field performance of Pinus halepensis planted in Mediterranean arid conditions: Relative influence of seedling morphology and mineral nutrition. New For. 37(3):313-331. DOI: 10.1007/s11056-008-9126-3

Rascher, U., M. Liebig, and U. Lüttge. 2000. Evaluation of instant light-response curves of chlorophyll fluorescence parameters obtained with a portable chlorophyll fluorometer on site in the field. Plant Cell Environ. 23(12):1397-1405. DOI: $10.1046 / j .1365-3040.2000 .00650 . x$

Park, B.B., J.K. Byun, W.S. Kim, and J.H. Sung. 2010. Growth and tissue nutrient responses of Fraxinus rhynchophylla, Fraxinus mandshurica, Pinus koraiensis, and Abies holophylla seedlings fertilized with nitrogen phosphorus, and potassium at a nursery culture. J. Korean For. Soc. 99(1):85-95.

Park, B.B., J.K. Byun, J.H. Sung, and M.S. Cho. 2013. Study of optimal fertilization with vector analysis in hardwood and softwood seedlings. J. Agric. Life Sci. 47(5):95-107.

Phillion, B.J. and M. Libby. 1984. Growth of potted black spruce seedlings at a range of fertilizer levels. Plant Propagator 30:10-11. 
Richards, N.A., A.L. Leaf, and D.H. Bickelhaupt. 1973. Growth and nutrient uptake of coniferous seedlings: Comparison among 10 species at various seedbed densities. Plant Soil 38(1):125-143.

Ritchie, G.A. 1984. Assessing seedling quality. In Forestry nursery manual: production of bareroot seedlings (pp. 243-259). Springer Netherlands.

Salifu, K.F. and D.F. Jacobs. 2006. Characterizing fertility targets and multi-element interactions in nursery culture of Quercus rubra seedlings. Annu. For. Sci. 63(3):231-237. DOI: 10.1051/forest:2006001

Šestak, Z., J. Catsk, and P.G. Jarvis. 1971. Plant photosynthetic production manual of methods. The Hague. Netherlands: Hertogenbosch.

Shin, J.A., Y.H. Son, S.G. Hong, and Y.K. Kim. 1999. Effect of N and P fertilization on nutrition use efficiency of Pinus densiflora, Larix leptolepis, and Betula platyphylla var. japonica seedlings. Korean J. Environ. Agric. 18(4):304-309.

Sung, H.I., G.S. Song, Y.G. Cha, and J.J. Kim. 2011. Characteristics of growth and seedling quality of 1-year old Quercus myrsinaefolia by shading and fertilizing treatment. J. Korean For. Soc. 100(4):598-608.

Switzer, G.L. and L.E. Nelson. 1963. Effects of nursery fertility and density on seedling characteristics yield, and field performance of lobloly pine (Pinus taeda L.). Soil Sci. Soc. Amer. Proc. 27(4):461-464. DOI: 10.2136/sssaj1963. $03615995002700040028 x$

Teng, Y. and V.R. Timmer. 1995. Rhizosphere phosphorus depletion induced by heavy nitrogen fertilization in forest nursery soils. Soil Sci. Soc. Amer. J. 59(1):227-233. DOI: 10.2136/sssaj1995.03615995005900010035x

Timmer, V.R. and B.D. Miller. 1991. Effects of contrasting fertilization and moisture regimes on biomass, nutrients, and water relations of container grown red pine seedlings. New For. 5(4):335-348.

Timmer, V.R. and G. Armstrong. 1987. Diagnosing nutritional status of containerized tree seedlings: Comparative plant analyses. Soil Sci. Soc. Amer. J. 51(4):1082-1086. DOI: 10.2136/sssaj1987.03615995005100040048x

Thompson, B.E. 1985. Seedling morphological evaluation - What you can tell by looking. p. 59-71. In: M.L. Durvea (ed.). Proceedings, evaluation seedling quality: Principles, procedures and predictive abilities of major tests. Forest Research Lab. Oregon State Univ. Corvallis. USA.

Trubat, R., J. Cortina, and A. Vilagrosa. 2008. Short term nitrogen deprivation increases field performance in nursery seedlings of Mediterranean woody species. J. Arid Environ. 72(6):879-890. DOI: 10.1016/j.jaridenv.2007.11.005

Van den Driessche, R. 1988. Nursery growth of conifer seedlings using fertilizers of different solubilities and application time, and their forest growth. Can. J. For. Res. 18(2):172-180. DOI: 10.1139/x88-027

Way, D., S. Seegobin, and R. Sage. 2007. The effect of carbon and nutrient loading during nursery culture on the growth of black spruce seedlings: A six-year field study. New For. 34(3):307-312. DOI: 10.1007/s11056-007-9053-8 